Meta

Journal des traducteurs

Translators' Journal

\title{
Translation and Interpretation in Japan
}

\section{Sen Nishiyama}

Volume 28, numéro 1, mars 1983

La traduction dans le monde

Translation around the World

URI : https://id.erudit.org/iderudit/003740ar

DOI : https://doi.org/10.7202/003740ar

Aller au sommaire du numéro

Éditeur(s)

Les Presses de l'Université de Montréal

ISSN

0026-0452 (imprimé)

1492-1421 (numérique)

Découvrir la revue

Citer cet article

Nishiyama, S. (1983). Translation and Interpretation in Japan. Meta, 28(1),

95-110. https://doi.org/10.7202/003740ar

Ce document est protégé par la loi sur le droit d'auteur. L'utilisation des services d'Érudit (y compris la reproduction) est assujettie à sa politique d'utilisation que vous pouvez consulter en ligne.

https://apropos.erudit.org/fr/usagers/politique-dutilisation/ 


\section{TRANSLATION AND INTERPRETATION IN JAPAN}

Sen Nishiyama

Translation has played a major role in the development of the Japanese language. Until about the seventh century, Japanese remained unwritten. Then the spread of Buddhism from China brought many Chinese to Japan as Buddhist priests, and Japanese were sent to China to train as monks. The new religion was accompanied by a cultural wave from the mainland which also brought over Chinese scholars and writers. The temples became centres of intellectual ferment, and soon there was strong motivation to translate Chinese classics and religious works into Japanese. That in turn necessitated inventing a writing system for Japanese, and the result was the adaptation of the Chinese characters - called kanji in Japanese - to a language for which they were basically quite unsuited. For nothing could be further from the truth than to suppose from the look of the writing that Japanese is like Chinese. First the characters acquired entirely new pronunciations, those of the Japanese words for the concepts they symbolized. But the adaptation dit not stop there: since sequences of characters were calqued from Chinese phraseology regardless of the fact that word order differed in Japanese, the Japanese added diacritics to signal the order of decoding in their own language. Furthermore Japanese is not truly a 'tone' language like Chinese (in which the meaning of words can be changed radically by altering the tone contour with which they are pronounced), yet there are prosodic inflections that have phonemic value. Morphologically it is an agglutinative language - quite the contrary of Chinese, which is monosyllabic.

We quote Professor Wellisch on the heritage this awkward fit has bequeathed:

It can safely be said that no other language has ever been burdened with a writing system so patently inappropriate for its structure and phonology, and at the same time so complex and ambiguous in its application. Yet such is the power of script conventions that even the most unwieldy system, once firmly ensconced and anchored in religious tradition, a large body of literature, and national pride, is almost impossible to replace by another system save by a foreign dictatorial force bent on such a purpose. This, for better or worse, the Japanese have not yet encountered, although they came close to it after their defeat in World War II. (Wellisch, p. 84)

The Japanese still feel a deep-rooted familiarity with Chinese. Japanese scholars are still translating regularly from it. Although their output today may look small compared with the mass of translations from Western languages, especially English, it shows that the cultural link between Japan and China 
remains alive. On the other hand, English, French, etc., are 'remote' languages to the Japanese, even after more than a century of fairly unrestricted contact.

The first Europeans to establish contact with Japan were the Portuguese. Their navigators reached the southern islands in 1544. By the following year, Saint Francis Xavier arrived from Macao to proseletyze. He brought with him his interpreters : three Japanese converts from China who spoke Portuguese and Spanish. There ensued half a century during which the spread of Catholicism among the people was accompanied by the import of military know-how and hardware for their rulers - as readers and televiewers of Shogun know. In 1593 a Japanese translation, or rather adaptation, of Aesop's Fables was made : condensations of some of the fables, the aim being to teach moral principles. Aesop must have struck a chord in the Japanese mentality, for there have been many translations of him since. We can surmise that sections, at least, of the Bible must have been translated by the missionaries and their Japanese interpreters; however, there is no record of any being published.

How deep was this Western penetration? Certainly the religious conversions were partly motivated by curiosity about things Western. Anyway it was brought to a violent halt when Ieyasu Tokugawa united the country under the Shogunate in the early seventeenth century and decided that Catholicism was a divisive influence. He therefore banned Christianity at home and closed the country to Europeans; and so it was to remain for 238 years - with one exception.

Unable to deprive themselves completely of Western imports, the Shoguns allowed the Protestant Dutch to maintain a single, well-controlled trading settlement on a small island in the bay of Nagasaki. Though it was tenuous, this trading link survived the whole epoch of isolation, and by it Western knowledge continued to trickle in. The Japanese were particularly interested in Western medicine. A small team of Japanese scholars studied Dutch for the express purpose of translating a Dutch treatise on anatomy, an undertaking that not surprisingly took them four years.

The Dutch thus acquired a scientific reputation comparable with that enjoyed by Chinese scholars in Japan. To appreciate the importance of this, it is necessary to consider the order of classes in old Japanese society, which was rigidly structured. At the top came the Warriors (Bushi, or Samurai, with their code of bushido, meaning 'way of the Bushi'); then the Farmers and Craftsmen in that order; and finally the Merchants. Simply as merchants, therefore, the Dutch would have been at the bottom. However, there were always two groups that stood outside the hierarchy of the main classes and drew recruits from all of them: these were the clergy and the scholars, beneficiaries of a tradition that goes back to the introduction Chinese Buddhism. Even today, the honorific suffix -sense is used after the names of teachers instead of the more commonplace -san.

It seems likely that the first Japanese adaptations of Gulliver's Travels (1774) and Romeo and Juliet (1810) were made by way of Dutch. (Both have since been translated several times directly from English.) Since Dutch was virtually the only language of communication between Japan and the West, some 
Occidentals even thought that Dutch was the official idiom of the Japanese imperial court!

The modern era of Japanese history, both political and cultural, opened dramatically in 1853. By that time the 'West' included America as well as Europe, and especially the United States spreading its interests across the Pacific. In that year an American naval squadron under Commodore Perry forced its way, by a show of modern artillery, into the Bay of Yedo (now Tokyo Bay), and the Japanese agreed per force to open Yokahama to trade with the major Western powers, namely the USA, Russia, England and France together with the still-present Dutch. Sir Ernest Satow, a contemporary witness of these developments whom we shall have occasion to quote liberally in the next few pages, summed up the situation this way:

Probably no one was more agreeably surprised than Commodore Perry at the comparative ease with which... he obtained a Treaty. No doubt the counsels of the Dutch agent at Nagasaki were not without their effect, and we may also conjecture that the desire which had already begun to manifest itself among some of the lower Samurai for a wider acquaintance with the mysterious outer world was secretly shared by men in high position. (Satow, p. 43.)

Yet reopening the channels of communication was not always such plain sailing, because there was strong opposition from fractions within the Shogunate who feared that political disruption would ensue - rightly, as events soon proved. The intellectual renaissance set off by the new contacts proved, however, to be the stronger force.

One early consequence of the reopening was that by 1855 the Shogunate was obliged to set up a translation bureau to deal with the surge of diplomatic and consular correspondence. The bureau expanded. The truth is, it also served as an intelligence and commercial research agency. Eventually it was to provide the nucleus for a foreign language school (Kaiseijo) in Tokyo which has attained university status as the National Institute of Foreign Studies. Meanwhile the Shogunate realized that its translation bureau might enable it to corner something of a communications monopoly, and so it forbad the setting up of translation bureaux elsewhere in the country.

While there were already Dutch translators available in Japan, there was a dearth of Japanese knowing English, French, etc. (Within the trading settlements themselves, a pidgin soon sprang up, as it did on the China coast: cf. Satow, p. 23.) Stories have come down to us about some of the early Japanese speakers of English. One of them was Manjiro (later known as Manjiro Nakahama), shipwrecked as a youth, picked up by an American whaling ship and taken to Massachussetts, where he became the first Japanese to be educated in the United States. On his return to Japan, bringing a Webster's Dictionary with him, he was naturally fitted to become an interpreter. Yet he was not allowed to interpret officially for a long time; possibly there were difficulties due to his class origin. Meanwhile he worked in the background as an influential teacher. Another Japanese, known in English as Joseph Hilo, even became an American citizen and secretary in the US consulate at Yokohama. Yet another of the same generation, Yugichi Fukazawa, started with the advantage of being 
born into the warrior class. He became a scholar and learned Dutch at the Nagasaki settlement. He then moved to Yedo (the old name for Tokyo) and opened a small school teaching Dutch and some other Western subjects. Hearing that new foreigners were establishing themselves at Yokahama, he went there and saw signs in what looked like Dutch but which he could not understand. They were in English! So he obtained an English-Dutch dictionary. Foreseeing that English was going to be more important than Dutch, he set about learning the former using a Dutch-English and an English-Chinese dictionary. Later he joined the first Japanese diplomatic mission to the United States and also visited Europe. When he came home, he published a travel book in Japanese, Customs of the West, which became a best-seller.

The period 1855-1868 was one of political turmoil as the parties of the Shogun, of the most powerful provincial governors (daimos, sometimes translated as 'barons') and of the Emperor (Mikado) were locked in a struggle for hegemony. In the end the imperial faction won a victory that has not since been disputed. The shoguns were hereditory viceroys. During their long period of supremacy, the Emperor was a mere puppet. However, the shoguns had themselves in course of time become puppets in the hands of their principal advisors. To quote Satow again:

The political system was enabled to hold together solely by the isolation of the country from the outer world. As soon as the fresh air of European thought [one must remember Satow was British] impinged upon this framework, it crumbled to ashes like an Egyptian mummy brought out of its sarcophagus. (Satow, p. 38.)

While this was going on, the Western powers stood on the sidelines waiting to back the winner, but not adverse to bouts of gun-boat diplomacy when the times were ripe. They too needed translators and interpreters, the more so as they suffered from a very imperfect understanding of Japanese politics and ways of thought:

...the literature of Japan was almost entirely unknown to Europeans, and the existing keys to the language were ridiculously inadequate. The only historical works accessible to foreigners were the scanty Annales des Dairi, translated by Titsingh with the aid of a native [i.e. Japanese] Dutch interpreter and edited by Klaproth with a degree of bold confidence that nothing but the position of a one-eyed man among the blind can give; and a set of chronological tables, translated by Hoffman for Siebold's Nippon. It is no wonder, therefore, if at the outbreak of Treaty negotiations, the foreign representatives were at a loss to appreciate the exact nature of the political questions that confronted them. (Satow, p. 34.)

Since Occidentals knowing the Japanese language were just as rare as the converse, it soon became clear to the diplomats that they would have to train language staff for themselves. Thus in 1861, the British Foreign Office, which already had staff diplomatic interpreters stationed in China, announced a competition for student interpreterships in Japanese. One of the successful candidates was a young student at University College, London, named Ernest Satow. He was later to advance in the diplomatic service to the rank of ambassador and a knighthood, and he wrote a handbook of protocol which is still a standard reference work for diplomats. However, it is another of his 
books, A Diplomat in Japan, that interests us here, and from which, indeed, we have been quoting. In it he gives a fascinating account of his training and early experience during those formative years of modern Japan. At first the Foreign Office sent him to Pekin, having mistakenly concluded, from a superficial acquaintance with the kanji, that it would accelerate the learning of Japanese if one first learned the Chinese characters in China. Once he reached Japan, however, Satow not only learned the language very industriously but also showed brilliance at acquiring insights into Japanese society. As a result he made himself invaluable to the chiefs of mission under whom he served, not only as translator and interpreter, but also - and even more actively than his counterparts in the Shogunate bureau - as an intelligence gatherer and political adviser. It was the arrival of Satow and his colleagues at Yokahama which made 'relay' interpreting and translating via Dutch obsolete:

At an interview with Japanese ministers they [the Dutchmen] used to translate into Dutch what the British minister said, and the native [Japanese] Dutch interpreters translated this again into Japanese. The reply had in the same way to go through two men. But when Siebold [Satow's colleague] or I interpreted, the work was performed more quickly and more accurately, because we translated direct into Japanese. It was the same with official correspondence. (Satow, p. 157f.)

By the time Satow finished his tour of service in 1869, the new Meiji regime was firmly in power; the capital had been moved from Kyoto to Yedo, and Yedo had been renamed Tokyo. The first English-Japanese dictionary had been published at Satsuma (Kagoshima today), the province where the first Portuguese guns had been landed in the sixteenth century. This was more than a coincidence, for Satsuma had always been more progressive than the other provinces, and had a tradition of Western scholarship as well as gunsmithery. The dictionary, however, had of necessity been printed not in Satsuma but at Shangai (on the China coast), because none of the Japanese presses possessed an English type font yet. But by 1869 , Western presses were being imported. In the last chapter of his book (p. 409), Satow records with satisfaction that on January 30 of that year, his English translation of an important Japanese state paper was published in The Japan Herald. Newspapers were making their appearance in Japan.

One feature of society that bothered Satow was the low status which the Japanese accorded to interpreters. This was - and still is - in surprising contrast to the high esteem enjoyed by Japanese translators. Even today, the latter are addressed with the -sense honorific (see our earlier remark on the status of scholars), but not the former. On one occasion, relates Satow, the Japanese had written up our official titles on the doors of the rooms intended for us, and mine had been rendered by "tongue officer", a euphemism for interpreter; this I immediately had done away with, and my name substituted, for in Japan the office of interpreter at that time was looked upon as only fit for the lowest class of domestic servants, and no one of samurai rank would speak a foreign language. I often had to fight pretty hard with Japanese of rank in order to ensure being treated as something better than a valet or orderly. (Satow, p. 259.)

The reason for this discrepancy is that translating has always been assimilated to scholarship, whereas interpreting was - until recently anyway - associated with trade. 
The final decades of the nineteenth century saw intense activity in translation from English and the other major Western languages. It surely cannot be said that the Japanese translators were daunted by difficulties. Besides translations from Shakespeare (always popular in Japan - there is even an annual learned review, Shakespeare Translation, published in Tokyo), there were translations of Dickens and J.S. Mills. The last, like translations of other intellectual works, had a strong impact on the Japanese intelligentsia and ruling class. The Satsuma dictionary was widely used; it proved invaluable at the time, but of course it had many gaps in it. The major problem was, as usual in such situations, specialized terminology. Commodore Perry tells, in his memoirs, how the people of Okinawa were not familiar with mints for coining money, but thought it would be a good idea to have one. So they sent a request to their suzerain, the Northern Japan government, for permission to import it. Unfortunately a Japanese translator rendered mint as 'leaf of mint', so the Northern government understood that the Okinawans wanted to import peppermint from the United States.

This was the period known in retrospect as the Era of Bold Translations, because of the liberties which its translators took. Often they were taken out of sheer ignorance: ignorance on the part of the translators, and ignorance on the part of the literary critics, few of whom knew foreign languages. Nevertheless, translation soon became so popular as to excite competition between translators, and rivals sometimes spotted one another's errors. Yet Japanese etiquette forbids one to confront somebody directly with his mistakes; so the method resorted to was to spread the criticisms by word of mouth behind the translator's back. A notorious exception to this rule occurred when a translator rendered the English expression lion at bay as 'lion roaring on the shore'. A famous scholar pointed it out in a journal and attacked the translator. Whereupon honour obliged the hapless translator had to commit suicide.

In 'bold' translations, the translator often cut the Gordian knot of a difficult passage by simply leaving it out. A good deal of summarizing was practised. There was also a general problem of selecting a level of style for the new epoch. The Japanese literary register up till then had evolved through adaptations from Chinese, and therefore differed widely from the spoken register with its many levels of respect towards the addressee (see below). The Bold Translators sought a compromise between literary tradition and modernity by blending a modicum of the spoken register into the literary one. The result of their attempts was that for a while the 'translation style' fluctuated between two poles.

Whatever their shortcomings, we must say for the translators of the period that they were very conscious of taking part in a mission to introduce Western culture. They started with the advantage that popular literacy was high, at least as high as in Europe at that time. We can surmise this because it is possible to compute the school population from the temple and other school records as well as from surveys of schools; while rice merchants' records enable estimates of the total population to be made even though there was no census yet. Even under the feudal regime, boys from all classes of society had been able 
to attend the temple schools, and the teachers (as we mentioned earlier) were also drawn from all classes.

The translators' mission being to aid in national modernization, it behoved them to write in a style that made for easy reading by the general public. The old literary register, with its Chinese word order modified by diacritics (see above), was intended for the elite of scholars. Hence the gradual but very marked shift during the late nineteenth century, and not only in translations, towards a written register closer to the spoken idiom. As a result, it is difficult for Japanese today to read mid-nineteenth-century writings - harder, say, than for contemporary English readers to understand Shakespeare. The Bold Translations would seem insufferably classical and stilted to present-day readers. By the turn of the century, the shift was almost over and a 'modern written Japanese' attained. It is close to the spoken language (sometimes called the 'abrupt' language), the major remaining differences being the final endings on verbs and the amount of polite suffixing.

While the written language was thus developing rapidly, the translators were improving their techniques. It was also a great period of original literary innovation under foreign influences. Translators did much to convey these influences; indeed many of the early Meiji novelists were themselves scholars and translators. The tradition of combining authorship and translation has continued to be stronger than in the West, where authors generally regard their translating activities as secondary. In Japan, on the contrary, translators are regarded with so much respect that authors are proud to list their translations alongside their original works. Both genres enjoy the same status. Conversely, the acknowledgement paid by famous writers to their translations has bolstered translating as a literary activity.

Perhaps one reason for this high esteem lies in the amount of creative adaptation required to cross the cultural gap between the societies of the 'remote' languages and that of Japan. One example of such creativity in translation is the Japanese version of Jonathan Livingstone Seagull, which became a best-seller when it was adapted by a famous novelist into Japanese literary style. It is this gap, as much as language differences, which makes it harder to translate from English to Japanese than, say, from English to French. The 'cognitive dissonance' between Japanese and other cultures showed up startlingly in World War II, despite 'modernization' and to the consternation of many Westerners who thought they knew the country.

Today's Japanese are for the most part unaware of contribution translation made to fashioning their written language. Nevertheless, a great many of them have been involved in some form of translation themselves, especially in connection with the widespread use of foreign textbooks in higher technical education. When the present author returned to Japan from the USA in the 1930's, he was often called on to take part in 'reading groups'; that is to say, groups of students who would work together on an English textbook, taking turns to read out paragraphs from it in Japanese - in other words 'sight translation', a technique with which they had already become familiar at secondary school. 
World War II temporarily abolished English teaching from the schools and cut the Japanese off again from foreign literature and documentation. The consequence, immediately the war was over, was a veritable hungering after information from the outside world. It is illustrated by the enormous success which the Japanese edition of Reader's Digest enjoyed in the late 1940's. Its circulation quickly exceeded a million copies, and its publishers acquired the status symbol of occupying their own building in Tokyo. More recently, we ourselves were asked by a Tokyo taxi-driver, "By the way, sir, have you read Solzhenitsyn?"

The reading population of Japan in estimated at 90 million. It is hardly surprising, therefore, if the publishing industry is flourishing here. It publishes about 35000 titles a year, roughly equal to the output in the United Kingdom. The figure includes proximately 2250 new translation titles (i.e. it does not take account of reprints). Thus translations regularly represent $6-7 \%$ of new publications. The total of translations can be broken down a follows:

$\begin{array}{lc}1400 \text { from English } & 140 \text { from Russian } \\ 300 \text { from French } & 30 \text { from Italian } \\ 270 \text { from German } & 110 \text { from other languages. } \\ \text { (Source : Index Translationum) } & \end{array}$

For purposes of comparison, here are some figures from other countries :

\begin{tabular}{lcc} 
& Total translations & From English \\
\hline German Federal Republic & 4500 & 3000 \\
Italy & 2100 & 900 \\
France & 2000 & 1100 \\
\hline
\end{tabular}

The total for the USA is 2100 , but this represents only a very small proportion of its total publishing output of 80-85000 titles a year.

The distribution of the source languages for the Japanese translations correlates well with the extent to which Japanese are otherwise exposed to them both at home (for example through foreign-language teaching in Japanese schools) and abroad (particularly through foreign trade relations). Hence new trade relations with Latin America in recent years have been accompanied by more translations from Spanish and Portuguese. Earlier, before the second World War, relations with Germany were more prominent, and this has left its mark on medical terminology: for instance, the Japanese word for ' $\mathrm{x}$-ray' is derived from German Roentgen. English is the most widely taught foreign language, starting in junior high school (grades 7-9); but the level of proficiency attained only whets the graduates appetite for translations rather than enabling them to dispense with them.

It is also interesting to break down the Japanese total by broad subject areas:

$\begin{array}{lllr}\text { Literary } & 822 & \text { Arts } & 142 \\ \text { Social sciences } & 392 & \text { English language } & 136 \\ \text { Natural sciences } & 370 & \text { Languages \& linguistics } & 48 \\ \text { Philosophy } & 225 & \text { Industry } & 42 \\ \text { History } & 167 & \text { General } & 28\end{array}$

(Source: Japan Publishing Annual. The total is slightly higher than the Index Translationum one.) 
The number of 'literary' translations looks disproportionate because it includes two exceptionally popular genres : science fiction and detective stories. It must also be borne in mind the print runs very greatly from one publication to another; and there are the reprints to consider in addition. Consequently statistics of the numbers of titles do not reveal the whole situation. What is certain, though, is that the $6 \%$ or so of translations have a greater impact per title on the reading public than the native Japanese works do.

At the source of all this output are over 3700 Japanese publishing houses, of which 2900 are concentrated in Tokyo and several hundred others in Osaka. They are of all sizes, several of them very large. Translations are fairly evenly spread throughout the industry.

One of the smaller houses that are important in the translation field is Simulpress. It began in the 1960's as an offshoot of Simulinternational, a conference interpreting organization. It so happened that the parent company had done the interpreting at the Shimoda Conference, a meeting between Japanese and American intellectuals named after the place where Perry first landed. The interpretations were taped. There were so many good papers in English that Simulinternational decided to transcribe the Japanese interpretations from the tapes, edit them and put them out as a book entitled The AmericanJapanese Dialog. Simulpress was founded to handle the publication. It turned out to be a minor best-seller, enough to establish Simulpress's reputation for translations. Later the young firm reinforced its position with another bestseller, the translation of Brzezinski's The Fragile Blossom. It now publishes about 100 titles a year, half of them translations.

Publishing translations of popular English books has become very competitive. If a book is well reviewed in the original, the Japanese houses rush to put in for options on the translation rights. The ensuing negotiations are liable to be tough and complicated. The Japanese versions are distributed, like virtually all Japanese books, trade or paperback, through one of the book trade's ten national distribution networks. Every Japanese publisher has to market through these wholesale organizations, each of which controls one or more chains of bookstores. The largest is Toha; another big one is Nippan. Foreign publishers are often ignorant of this system, and so they tend to offer rights to the big Japanese houses, not realizing that they might get a better deal from a smaller house without any sacrifice of distribution coverage.

Sometimes, on the other hand, it is a translator who approaches a Japanese publisher, typically because he or she is in personal contact with the author of the book to be translated. Then the translator becomes involved in the negotiations, which must take care of many interests : the original publisher's royalties and the author's, the Japanese publisher's rights, and copyright protection in Japan, as well as the translator's own remuneration (see below). Usually, however, it is the Japanese publisher who selects the translator. The latter will probably be a member of the fairly large community of literary translators who are well known to publishers. For an important work the publisher may go to great lengths to secure the services of a translator who already has a reputation and even some fame. In this connection we should mention that in Japan, far 
from translators remaining anonymous or their names being relegated to small type in an inconspicuous position, their names are always featured on the covers of books just below the authors' seven if it is the translator's first publication. Such is the translator's prestige, which, as we have explained, perpetuates the traditional respect for translators as transmitters of knowledge and scholarship.

One factor which often protracts negotiations is that foreign publishers, particularly Americans lured by the size of the market, begin by asking prices that are too steep for the Japanese : say $\$ 50000$ down-payment plus 5\% royalty. What the foreigner is failing to take into account is that books, even hard-cover ones, sell very cheaply in Japan : most are priced at under 1000 yen - an astronomical-sounding figure if you do not know the currency, but actually equivalent to a mere $\$ 5$ or the price of three cups of coffee in Tokyo. So the foreigners have to back down, sometimes to as low as one tenth of their first asking price. They may even settle for just a royalty.

As for the time delay, though there are occasional instances of simultaneous publication in Japan and the originating country (the Fragile Blossom was one), there is usually a lapse of at least six months to a year between the original publication and the Japanese one.

In summary we can say that high-speed production processes and well-organized marketing make publishing a mass-market industry in Japan nowadays, as in other highly industrialized countries. Good copyright laws are therefore necessary for the maintenance of high standards in the face of potentially cuthroat competition - high standards not only of authorship but also of translation. There was no copyright in Japan in the Era of Bold Translations; but since then Japan has become a signatory of the Berne and other copyright conventions.

In the case of academic books the publishing procedure is different. The proposal to translate frequently comes in the form of a recommendation from a university professor. Some institutions even have committees for selecting works to be translated. Furthermore some universities have their own presses to facilitate publication. Often this type of book is only printed in short runs; so that the foreign publisher, knowing this, may ask for guaranteed sales of 500 or 1000 copies. Occasionally an overseas government agency like the US International Communications Agency (formerly USIS, the US Information Service) will obtain the rights and approach a Japanese publisher with a guarantee of buying a certain number of presentation copies - a form of subsidy. However, such cases are exceptional and do not constitute a program. Nor are we aware of any sustained assistance from the Japanese Ministry of Education, although there may be financial support from time to time on an ad hoc basis. The ministry's moral support is nevertheless important, because educational administration is highly centralized in Japan and the ministry exercises close control even over private schools. We should add that the pattern of schools and higher institutions is multifold: there are national, prefectural (i.e. provincial), municipal and private institutions at every level. All this ensures a market big enough to support good educational publishing without subsidies, and indeed the big publishers show themselves more adventurous than the ministry. 
Some literary translation is also done the other way: that is to say, out of Japanese into English and other languages. For this there are special funds available. The Japan Foundation, a semi-government agency, subsidizes English translations of contemporary literature as well as of the classics. So does the Toyota Foundation, a Japanese emulation of the Ford Foundation. Altogether about 150 titles a year are translated in Japan into other languages, mostly into English. In addition, a committee of Japan PEN selects short stories for translation into English by PEN members and publishes them in its periodical Contemporary Literature in Japan, which also contains English reviews and summaries of Japanese books.

This brings us to the magazine literature; for so far we have been talking almost entirely about books, though we did mention the Reader's Digest phenomenon. Many translations appear in the leading magazines and professional journals. There is a profusion of literary magazines in Japan, and a number of them publish translations into or out of Japanese. The professional institutes often publish English translations of part of their members' vast output of technical articles. Some institutes, like the universities, have selection committees to recommend papers for translation, usually into English. Yet these efforts are, alas, not enough to prevent foreigners occasionally accusing the Japanese of being secretive about their research - a false impression which can only be explained by foreign researchers' inability to read Japanese, and by the inadequacy of their own translation services!

We ought not to overlook the translations of Japanese publications done abroad, especially literary works, though they are somewhat outside the scope of this article. One encouragement to publish them is the UNESCO program for the translation of representative works into Western languages. Most Englishspeaking translators have recourse to Japanese collaborators, because otherwise they may miss some of the allusive connotations which the Japanese are so fond of in their literary style. For example, the title of a famous Japanese novel was translated as I am a Cat, when in our opinion a better translations would be Yours Truly, The Cat, because 'cat' is a metaphor for a high-ranking bureaucrat. Sometimes the author assists the translator, a method used by Seidensticker. For these translators it is Japanese which is the 'remote' language, and they must consequently face the same problems of cultural dissonance as translators into Japanese, but in reverse of course. Donald King, in one of his translations, at first changed "white tabsis" (literally 'foot bag', a peculiarly Japanese kind of stocking that is indented between the big toe and the other toes) to "white gloves" in order to avoid having to explain tabsis; though afterwards he changed it back again, for fear of being criticized for innacuracy.

Naturally, foreign translations of Japanese books can be very beneficial to their authors' reputations abroad. It is significant that Kawabata won the Nobel Prize for Literature only after Seidensticker's 1956 translation of Snow Country. Unfortunately there are far from enough foreign translators who know Japanese, and so they must still resort sometimes to the 'relay' system of translating indirectly through a third language. For his doctoral thesis, Erwin Reischauer translated into English the diary of a Japanese monk who voyaged 
to China during the T'ang dynasty. Later Reischauer noticed a French translation had appeared. To his surprise he found it was his English version retranslated into French without acknowledgement.

Once a decision has been taken in Japan to translate, the work is usually carried out quite fast. Non-specialized books of average length are completed in about a month, although longer or more difficult ones may take up to half a year. The majority of translators work on their own, but joint translations are fairly common too. The choice is not necessarily determined by length : for example, the 900 pages of Reischauer's The Japanese were translated by a single translator. (Incidentally, long single-volume English works are often published in two or three volumes in their Japanese editions.) At the extreme there are 'translation factories', typically run by a professor who parcels out the text to some graduate students and then skims through their drafts revising them before putting only his own name as translator on the cover. Other teams work in a more reputable professional way, and then of course all their names are featured. Even so, the publisher or the team itself may commission a revision from a more prestigious author, translator or subject specialist, who is then listed on the cover as 'supervisor'. This happens especially with scholarly publications and modern classics or near-classics. It is ultimately the supervisor's responsibility to ensure that the terminology is uniform; but most probably the team will have met and settled most of it before they got down to their work, especially if they foresaw a need to coin neologisms. It is not unknown for a famous author to be named as translator when it is really a 'ghost' translator who has done most of the work. But even then the named 'translator' must have enough knowledge of the source language to do some checking for accuracy, since it is his reputation which is at stake. Beyond that the publishers usually trust their translators and rarely check for fidelity.

Notwithstanding, the translations do get passed to in-house editors, who read them as they would an original Japanese manuscript and parley with the translators if they find anything they think would put Japanese readers off. The latter are not fussy about language norms; easy readability is their main criterion. On the other hand, the critics are quite a different matter: they can be very severe.

Payment for literary translation varies substantially. As it customarily includes a royalty, the remuneration can be high if the translation sells well. The usual royalty, is $5 \%$ of the retail list price, though it can go as high as $7 \%$ for a well-known translator. (The standard royalty for original works is $10 \%$.) To take an optimistic but quite credible illustration, therefore, if the royalty is $7 \%$ and the book sells 100000 copies at 1000 yen each, the translator's share will be 7000000 yen, or about $\$ 75000$. Contracts may, however, be entered into on a lump-sum basis, or combine lump-sum and royalty.

The main professional association is the Japan Society of Translators (JST). It grew out of a committee of Japan PEN which was formed to encourage Japanese-English translations (and which still publishes Contemporary Literature in Japan - see above). In 1954, UNESCO suggested to PEN that it establish an autonomous translator organization which would be eligible for membership in 
FIT, and JST was the result. It now numbers approximately 200 members. A few years later a small group headed by JST's founder split off and formed a splinter organization - but kept the same name, so that 'JST' now appears to have two addresses! The splinter group wanted the society to retain the PEN's atmosphere of a social club, but the majority opted for more of a 'professional institute' type of organization. The connection between authors and translators remains strongly in evidence all the same, as is consistent with the Japanese tradition: at the time of these lectures (1980), it is a famous translator from German who is president of both Japan PEN and JST (main branch). JST publishes the JST Bulletin, and receives wide publicity for its annual prizes, one of which is awarded to a translator and the other to a publisher. In 1979 it instituted the Mainichi Prize (named after the donor, a big newspaper), which was awarded that year for a new translation of Paradise Lost and for a translation of Ludwig Back's History of Iron (in 17 volumes!) These prizes, and the publicity surrounding them, are another mark of the high esteem enjoyed by translators in Japan.

Besides JST there are some smaller, looser organizations specializing in technical fields such as telecommunications or management. Some of these are semi-commercial and even act as correspondence schools. Finally there are the lone individuals, just as numerous in Japan as in the Western countries; for instance scholars translating in their own disciplines, for whom translation is an occasional sideline or a avocation. Consequently we will not venture a precise estimate of the total number of translators in Japan, but there must be several thousand.

The number is certainly large if we include all the commercial and technical translators. When these are considered, the imbalance between translation into Japanese and translation out of it in the literary field is somewhat redressed. A big impulse has come from the world-wide expansion of Japanese trade since the war. A few years ago this type of translation was more often than not very poorly done - as those who have had to cope with the foreign-language instructions for Japanese products may recall. There are still lapses, but the major corporations have made great efforts to improve that aspect of their image. This has led to the development of a 'two-tier' system of translation and revision in which the translation is first drafted by a Japanese and then edited (or 'revised', to use the Canadian term) by a native speaker of the target language. The problem remains that if the foreign editors do not know Japanese - which is often the case - they are prone to introduce translation inaccuracies in their quest for correct idiom. so the reverse procedure has also been tried, and looks potentially safer: that is to say, a native speaker of the target language undertakes the translation from the start, but in close consultation with a Japanese colleague for passages he does not understand. It is the method favoured, for instance, by The Japan Interpreter, the publication of the Japan Center for International Exchange, which is a non-profit organization for spreading knowledge abroad about our country. But since the articles selected for this journal are considered important ones, the editor goes one step further and sends the translations to the authors for checking. Unfortunately 
the reverse procedure produces the reverse inconvenience : when the authors do not understand English well, they wrongly contest parts of the translation.

However, the worst drawback of the two-tier system is the delay - about six months between the publication of the original articles and their translations in the case of The Japan Interpreter. That could be very serious in the marketing operations of a multinational like Sony Corporation, where timing may be no less important than accuracy and style. Early on, Sony tried the two-tier method for its English translations. To our surprise we discovered that sometimes what appeared to be translation errors were actually technical inaccuracies that had been overlooked in the Japanese originals. As a result, we have now gone over to a system of 'co-writing', whereby a Japanese technical writer and an English one both both work closely with somebody from the the design department, and the texts are composed simultaneously in both languages. That makes a reliable English text available much faster; and then from the English version the translations into other Western languages can be proceded with much more easily.

Quite another matter are the in-house technical translations that circulate within an organization, even at Sony. Though they are done by subject specialists, these people have not been trained in translating. What they produce therefore tends to be very literal, and might indeed prove incomprehensible to anybody but the translator were it not that people acquire a certain skill at decoding this kind of 'pidgin' Japanese - which is perhaps a pity, because otherwise they might press for normal Japanese text. The same is true of many of the translations turned out by the 'translation factories' that we referred to earlier, where a big-name professor farms out the translating to students; in which case the number of copies distributed may not be an indication of the amount of knowledge effectively transmitted. But at least when a book is published commercially, the publisher's editor looks it over and may revises it for naturalness; and the critics, who are influential in Japan, provide some incentive to improve standards.

The literalness of the less careful translations goes back to the way we Japanese are taught English, our principal foreign language. The teaching does not begin until junior high school. There the method is still generally the old 'grammar-translation' one, and the explanations are given in Japanese. This situation is consecrated by a century of tradition which is hard to change despite the criticism it has encountered in recent years. To be sure 'translation' forms part of the method, but it consists of translation glosses into a pidginized interlanguage using a word-for-word vocabulary; and the aim is to demonstrate knowledge of the source language, not to produce readable text in the target language.

For the aspiring professional translator there are nevertheless translation schools, and also correspondence course in the skilll. At the highest level there is the Tokyo Institute of Foreign Studies, whose origins we explained earlier. For further improvement there are magazines for translators. The professional institutes also provide some further education in the field. The Telecommunications Association is a good example of a professional institute 
sponsoring English technical writing courses that include some translation exercises. Theirs is one of the courses which can be taken by correspondence. Despite these training facilities, technical translations still tend to be too literal.

Where the differences between Japanese and English impose an artificiality of language that can perhaps never be overcome is in simultaneous interpreting. The present author, who was one of the first simultaneous interpreters in Japan, recalls that when the method was first proposed for international conferences in our country, many people - even an experienced translator like Reischauer - doubted it could be applied at all. The most prevalent of a number of problems it poses is the different order of sentence constituents, particularly the fact that the verb is placed at the end of Japanese sentences. (Of course this is a wellknown problem with German too, but in Japanese if affects main clauses as well as subordinate ones.) However, circumstances obliged a few of us to try simultaneous in the early 1950's. Then, about 1957, the US Embassy sent a party of Japanese interpreters to Washington for training at the State Department, where simultaneous was by then the rule. That proved to be the turning point, and nowadays simultaneous is in constant demand in Japan. Naturally the Japanese electronics industry supplies the home market with the necessary equipment, and has started to export it. Sony is now a major international supplier of lightweight systems.

Conference and liaison interpreting point up differences between Japanese and English that go well beyond sentence boundaries. There are problems of rhetoric and etiquette. For instance, a Japanese speaker is required by custom to start off by repeating in extenso the five-minute curriculum vitae with which the the chairman has just introduced him. The corresponding English at that point ought to be no more than, "Thank you, Mr. Hiro, for that flattering introduction, and I'd just like to add how glad I am to be here." But what does the interpreter do for the rest of the time? It is better for audience sympathy to be brief to the English listeners and simply explain why the repetition has been omitted.

Japanese conference interpreters are organized somewhat differently from their Western counterparts - or at any rate from the procedure favoured by AIIC. Probably because it was so difficult for clients to recruit them in the 1960 's, when they were really scarce, they find their work through agencies and not through the team system. Even now it is often a problem to find enough interpreters. Again a shortcoming has its origin in the education system, since schoolchildren and postsecondary students only learn foreign languages in their written form, with rare exceptions. The best known of the agencies is Simulinternational, which was started by a group of interpreters in the pioneer days of the sixties. It is used by the Japanese Ministry of External Affairs, which does not have staff interpreters of its own; and it has branched into conference organizing, proceedings publication, and so on. Another well-known agency is ISS.

The pay for our interpreters is on a par with international rates, though there is more than one grade. A top-class simultaneous interpreter receives about US $\$ 300$ a day, lower-grade interpreters about US $\$ 250$. This is all very good, yet 
it has not altogether eliminated the traditional lack of esteem for interpreters. The language reflects the descrepancy in the following way :

but

'to translate'

'to interpret'

'translator'

'interpreter' honyaku-tsuru tsuyaku-tsuru

honyaku-ka

tsuyaku

here the $k a$ is an agentive suffix, and its absence after tsuyaku marks lack of respect. Our own attempts to persuade colleagues and others to remedy this invidious distinction have so far been of no avail.

To round off this survey of professional activities, we must say something about two other media which require a great deal of translating in contemporary society, namely films and television. There is a surprisingly sharp, apparently contradictory, divergence of practice between the two : foreign films for cinema showing are all subtitled, TV programs (even films) are all dubbed. Dubbing was in fact tried many years ago in the cinemas, but audiences did not like it. It seems Japanese want to hear the original voices. So why all the dubbing for TV? Perhaps the writing system is again a burden: the small screen does not allow clear enough resolution of the characters. Furthermore a cinema audience sits captive in front of the screen throughout the showing, while TV viewers move around and depend on the sound to fill out gaps in their viewing. Now yet another new technology is upon us : multiplex-sound TV is available in Japan, and this allows telecasts of the original sound track and the dubbed one at the same time, leaving it to the viewer to choose.

As the Japanese are very high-tech oriented, they have not neglected the possibility of 'machine translation' by computer. (Perhaps 'electronic translation' would be a more appropriate term for it nowadays.) However, for a long time our writing system was again a serious drawback. That problem has been largely solved, since our own computer industry can now furnish terminals with Japanese keyboards and graphics. But the other language and cultural differences which beset all Japanese translators remain, and will be harder to overcome.

\section{REFERENCES}

SATOW, E. (1968) : A Diplomat in Japan, ed. G. Daniels (Oxford in Asia Historical Reprints), Tokyo, Oxford University Press.

WELLISCH, H.H. (1978) : The Conversion of Scripts - Its Nature, History, and Utilization, New York, Wiley - Interscience. 